\title{
391. Mikrochirurgische Modelle als Basis präklinischer Transplantationsforschung
}

\author{
A. Thiede, R. Engemann, E. Deltz, W. Timmermann, Th. Schang, K. Ulrichs ${ }^{1}$ und H. Hamelmann \\ Abteilung für Allgemein-Chirurgie der Universität Kiel, Hospitalstraße 40, D-2300 Kiel, \\ und ${ }^{1}$ Abteilung für Immunologie der Universität Kiel, Brunswiker Straße 2-6, D-2300 Kiel
}

\section{Microsurgical Models as Fundamentals of Preclinical Transplantation Research}

Summary. Using simple suture technqiues as a basis, it is possible to carry out major operations in rats using microsurgical methods and magnifying glasses. The microsurgical models of vessels, heart, small intestine, kidney, pancreas and liver transplantation enable us to analyse graft rejection (HVGR) and graft versus host reaction (GVHR), expecially in inbred rat strains. The strength of these reactions is dependent upon 1 . the degree of histo-incompatibility, 2. the quantity of allogeneic material, 3. the graft localization and 4. the immunological manipulation of donor and recipient. The physiological orthotopic models are of greatest preclinical relevance.

Key words: Microsurgery - Organ transplantation.

Zusammenfassung. Aufbauend auf Grundnahttechniken lassen sich mit optischen Hilfsmitteln und mikrochirurgischen Methoden größere Operationen an Ratten durchführen. Mit den mikrochirurgischen Modellen Gefäß-, Herz-, Dünndarm-, Niere-, Pankreas- und Lebertransplantation können mit Inzuchtstämmen grundsätzliche Phänomene wie Transplantatabstoßung (HVGR) bzw. Transplantat gegen Wirt Reaktion (GVHR) analysiert werden. Die Stärke dieser Reaktionen ist abhängig 1. vom Histoinkompatibilitätsgrad, 2. von der Menge des allogenen Gewebes, 3. von der Transplantatlokalistation und 4. von der Manipulation des Immunsystems von Spender und Empfänger. Die voll physiologischen orthotopen Modelle haben dabei die größte präklinische Relevanz.

Schlüsselwörter: Mikrochirurgie - Organtransplantation.

\section{Möglichkeiten des EDV-Einsatzes in der Chirurgie}

\author{
R. Schunck und R. Haunhorst \\ Evangelisches Krankenhaus, Chirurgische Abteilung (Chefarzt: Prof. Dr. G. H. Ott), \\ D-5300 Bonn-Bad Godesberg
}

\section{Possibilities for the Application of EDP in a Surgical Unit}

Summary. The wide range of possibilities for the use of modern computers in a surgical unit are described. Essential preconditions are the use of documentation-adapted forms, key systems geared to user requirements, complete documentation and data collection. Data processing and evaluation, use in the clinical cancer register, text processing and accounting are shown as some of the potential applications.

Key words: Documentation - EDP key systems - Clinical cancer register - Accounting.

Zusammenfassung. Dargestellt werden die breiten Einsatzmöglichkeiten eines modernen Rechners in einer chirurgischen Abteilung. Als Voraussetzungen müssen erfüllt sein: der Einsatz von dokumentationsgerechten Arbeitspapieren und anwenderfreundlichen Schlüsselsystemen sowie die lückenlose Dokumentation und Datenerfassung. Als Einsatzmöglichkeiten werden demonstriert : die Datenbearbeitung und -auswertung, der Einsatz im Klinischen Krebsregister, bei der Textverarbeitung und im Abrechnungswesen.

Schlïsselwörter: Dokumentation - EDV-Schlüsselsysteme - Klinisches Krebsregister - Rechnungswesen. 